\title{
SHOX Gene
}

National Cancer Institute

\section{Source}

National Cancer Institute. SHOX Gene. NCI Thesaurus. Code C75403.

This gene is involved in transcription and growth. 